\title{
Impact of Nursing Staff Perception of Work Environment on Turnover Rate in Hemodialysis Unit
}

\author{
ANGHAM A. MOHAMMED, M.Sc.; MHASEN ISMAIL, D.N.Sc. and FATMA A. ABED, D.N.Sc. \\ The Department of Nursing Administration, Faculty of Nursing, Cairo University
}

\begin{abstract}
Background: The nursing work environment is complex with many variables affecting the nurses' perception and work satisfaction. The strongest predictor of nurse's job dissatisfaction and intent to leave a job is personal stress related to the practice environment. Negative work environments demoralize nurses and contribute to the development of unsafe working conditions, which are unhealthy and highly associated with nursing job dissatisfaction, low productivity, and high turnover. High nurse turnover in healthcare facilities can negatively affect the ability of hospitals to meet patient needs, provide quality care and increases both direct and indirect labor costs.
\end{abstract}

Aim of Study: To explore the impact of nursing staff perception of work environment on turnover rate in hemodialysis unit.

Subjects and Methods: A descriptive correlational design was utilized to collect data from A convince sample of nursing staff working in the selected unit (hemodialysis unit) during the time of data collection (from May to September 2017) at a governmental University hospital. Data was collected by using two tools:

The Practice Environment Scale-Nursing Work Index (PES-NWI) questionnaire and turnover rate sheet.

Results: There were no significant relation between nursing staff perception of work environment and educational level, there were a high positive relation between nurses perception of work environment and years of experience and there were dramatically increase of turnover rate over the years.

Conclusion: Poor nurse work environment is the underlying factor of nursing turnover.

Recommendation: Improving nurse work environment should be emphasized through policy to retain nurses in the workforce; Further research is needed to investigate the tools, guidelines and interventions used by managers in the nursing field to create healthy and welcoming working conditio ns.

Key Words: Hemodialysis unit - Nursing staff - Work enviornment.

Correspondence to: Dr. Angham A. Mohammed, The Department of Nursing Administration, Faculty of Nursing, Cairo University

\section{Introduction}

A NURSING practice environment refers to the organizational characteristics of a work setting that facilitates or constrains professional nursing practice $[1,2]$. Conducted a study to evaluate the effects of work and physical environment on nurses' perceptions and attitudes of service quality. These researchers analyzed work environmental and physical factors on the basis of service quality and the commitment of nurses to the hospital. Data from the study reveal that physical factors such as safety, work space quality, and environmental factors such as communication and support from supervisors, have a positive impact on a nurse's perception of service quality and commitment to stay in the hospital.

Reports by the International Council of Nursing indicate that a current shortage of nurses and high turnover rate in the healthcare system is due to the working environment. An HWE has been associated with increased nurse retention, job satisfaction, decreased turnover, safer healthcare practices, and better patient outcomes. Negative work environments demoralize nurses and contribute to the development of unsafe working conditions, which are unhealthy and highly associated with nursing job dissatisfaction, low productivity, and high turnover [3].

Turnover is a symptom of a poor work environment is likely to lead to higher provider costs, such as in recruitment and training of new staff and increased overtime and use of temporary organization staff to gaps; turnover costs also include the initial reduction in the efficiency of new staff and decreased staff morale and group productivity International Council of Nurses [4]. Nurses' turnover is defined as an individual movement across membership boundary of an organization [5] . According 
to the survey, the average cost of turnover for a bedside $\mathrm{RN}$ ranges from $\$ 38,900$ to $\$ 59,700$ resulting in the average hospital losing $\$ 5.13 \mathrm{M}$ $\$ 7.86 \mathrm{M}$, annually. Each percent change in RN turnover will cost/save the average hospital an additional \$410,500 [6].

\section{Significance of the study:}

Work environments must be positive and healthy to promote professional nursing practice as well as positive patient and nurse outcomes, healthy work environments for nurses were hypothesized to impact group processes and thereby work effectiveness as reflected in patient outcomes (patient satisfaction, therapeutic self care, falls and nurse-assessed risks).

Hemodialysis nursing staff provides continues care for critical patients in a complex environment with highly technical equipment and involving multidisciplinary providers, therefore working environment issues dominate problems associated with nursing care. Research in hospitals has indicated that one factor that contributes to the nursing turnover is nurses' negative perceptions of the work environments.

Turnover is destructive to nursing and patient outcomes as it leads to losing competent and qualified nurses. Turnover rate can have negative consequences as costs associated with recruitment and orientation of new nurses, effects on normal daily work flow in the unit and increases the work load and stress on the remaining nurses, loss of experienced nurses. Numerous studies have linked work environment and nurses' job satisfaction to nursing turnover.

\section{Research question:}

What is the impact of nursing staff perception of work environment on their turnover rate in the selected setting?

\section{Subject and Methods}

\section{Research design:}

Descriptive correlational design was utilized to achieve the aim of this study.

\section{Setting:}

The study was carried out at a university hospital. The selected unit is hemodialysis unit.

The selected unit includes 24 machines divided into two parts negative (patients without virus C) and positive (patients with virus $\mathrm{C}$ ), the number of nurse in the unit 40 nurses.

\section{Subjects:}

A convince sample of nursing staff working in the selected unit (hemodialysis unit) were constitute study sample (40).

\section{Tools of data collection:}

Data was collected through utilizing the following tools.

1st Tool:

It was composed of two parts:

$1^{\text {st }}$ part:

Demographic data sheet that was developed by the researcher and include: Nurse's code, age, gender, marital status, education, years in nursing, years in nephrology nursing, and job title.

\section{2nd part:}

Nursing staff perception of work environment. The Practice Environment Scale-Nursing Work Index (PES-NWI) developed by Lake [7] that measure the practice environment, it consists of 31 items in five subscales measure: (Nurse Participation in hospital affairs, nursing foundations for quality of care, staffing and resources adequacy, manager ability, leadership and support of nurses, collegial nurse-physician relations), the researcher comprises 28 items, removed Three item (Use of nursing diagnosis, Philosophy of nursing pervades environment \& High standards of nursing care expected) from the second subscale. Nurses have to rate each item on a scale of 3 (strongly agree) to 1 (strongly disagree). The investigator modified the tool in the part of demographic data and nursing foundations for quality of care.

\section{2nd tool: Turnover rate:}

Instrument using to obtain data about turnover rate in the selected hemodialysis unit, it composed of sheet divided by months and years to collect the data and statistical equation to calculate the rate of turnover. Turnover rate tool developed by Seada [8].

$$
\frac{\text { Total N of separation (Year) }}{\text { Average N of employee (Year) }} \times 100
$$

\section{Validity and reliability:}

The modified tools were formulated and submitted to seven experts in the field of nursing administration and quality assurance departments from the faculty of nursing and the selected hospital to assess the content validity. Reliability was assessed to confirm the validity of the tools. 


\section{Methods of data collection:}

Up on receiving the formal approval through formal channels. The investigator got a letter from faculty of nursing seeking for the approval of administrative personnel of Cairo University hospital. Separate letter was handed to the managers exploring purpose, nature and significance of the study. The investigator explained the aim, nature, and significance of the study for every eligible nurse to obtain their acceptance to participate in the study. Then, the investigator obtained their acceptance in a written form. During data collection the investigator handed the questionnaire sheets individually to the nurses in their units then the investigator explained the questionnaire to them and asked them to fill it. The investigator waited until the participants filled the questionnaire and was ready to answer any question. After completion of filling the questionnaire the investigator collected them. Data was collected over a period of 5 months from May 2017 to September 2017. Then turnover data sheet used by the investigator to collect the data from the personnel records office in the selected hospital by retrospective method then equation was utilized to assess turnover rate through 2015, 2016 \& 2017.

\section{Ethical considerations:}

The study proposal was approved by the ethics and research committee in the faculty of nursing. Official permissions to conduct the study were secured. All participants gave their oral informed consent to participate in the study sample. They were informed about the study purpose, procedure and about their rights to refuse or withdraw without giving reasons. They were reassured about the anonymity of the information collected, and that it would be used only for the purpose of scientific research.

\section{Statistical analysis:}

The collected data will be categorized, scored, tabulated, and analyzed by computer using statistical package for social science (SPSS) version 20. Descriptive statistics will be used in the form of frequency distribution and percentages. ANOVA $\&$ Pearson correlation coefficient statistical tests were applied for data analysis.

\section{Results}

Table (1) clarified that the majority of the studied sample $(87.5 \%)$ was females. Also around half the sample (55\%) was in the age group 21-30 and the majority of the sample (90\%) was married.
Around two thirds (65\%) had Technical school of nursing degree while the rest had Technical nursing institute degree. Around one third of the sample (37.5\%) had 5-9 years of experience in nursing while a quarter $(25 \%)$ had $<5$ years. Nearly half $(47.5 \%)$ had $<5$ years of experience in kidney dialysis unit while around quarter $(22.5 \%)$ had 59 years.

It was clear from Table (2) that the highest perception of nurses was about Nursing Foundations for Quality of Care (mean=3.01) while the lowest perception was about Staffing and Resource Adequacy (mean=1.76).

Table (3) shows that the turnover ratio has increased dramatically over the years.

The result from Table (4) indicated that there is a negative significant relationship between total work environment and turnover rate as $p=-0.342$, $r=-0.031$ *.

Table (1): Percentage distribution of the demographic characteristics of Nursing Staff ( $\mathrm{N}=40)$.

\begin{tabular}{|c|c|c|}
\hline Variable & No. & $\%$ \\
\hline \multicolumn{3}{|l|}{ Gender: } \\
\hline Female & 35 & 87.5 \\
\hline Male & 5 & 12.5 \\
\hline \multicolumn{3}{|l|}{ Age (years): } \\
\hline $21-30$ & 22 & 55.0 \\
\hline $31-40$ & 10 & 25.0 \\
\hline$>40$ & 8 & 20.0 \\
\hline \multicolumn{3}{|l|}{ Marital status; } \\
\hline Single & 4 & 10.0 \\
\hline Married & 36 & 90.0 \\
\hline \multicolumn{3}{|l|}{ Educational level: } \\
\hline Technical school of nursing & 26 & 65.0 \\
\hline Technical nursing institute & 13 & 32.5 \\
\hline Bachelor of nursing & 1 & 2.5 \\
\hline \multicolumn{3}{|l|}{ Years of experience in nursing: } \\
\hline$<5$ & 10 & 25.0 \\
\hline $5-9$ & 15 & 37.5 \\
\hline $10-14$ & 7 & 17.5 \\
\hline 15 and more & 8 & 20.0 \\
\hline \multicolumn{3}{|c|}{ Years of experience in kidney dialysis unit: } \\
\hline$<5$ & 19 & 47.5 \\
\hline $5-9$ & 9 & 22.5 \\
\hline $10-14$ & 5 & 12.5 \\
\hline 15 and more & 7 & 17.5 \\
\hline \multicolumn{3}{|l|}{ Job title: } \\
\hline Staff nurse & 34 & 85 \\
\hline Charge nurse & 6 & 15 \\
\hline
\end{tabular}


Table (2): Mean and SD of nursing staff perception regarding work environment dimensions: $(\mathrm{N}=40)$.

\begin{tabular}{|c|c|c|}
\hline \multirow{2}{*}{ Perception } & \multicolumn{2}{|c|}{ Mean \pm SD } \\
\hline & SD & Mean \\
\hline $\begin{array}{l}\text { Nurse participation in dialysis } \\
\text { provider affairs }\end{array}$ & 2.63 & 0.51 \\
\hline $\begin{array}{l}\text { Nursing foundations } \\
\text { for quality of care }\end{array}$ & 3.01 & 0.74 \\
\hline Staffing and resource adequacy & 1.76 & 0.77 \\
\hline $\begin{array}{l}\text { Manager ability, leadership and } \\
\text { support of nurses }\end{array}$ & 2.45 & 0.64 \\
\hline Collegial nurse-physician relations & 2.98 & 0.67 \\
\hline Total & 2.60 & 0.52 \\
\hline
\end{tabular}

Table (3): Turnover rate among nurses in the studied sample $(\mathrm{N}=40)$.

\begin{tabular}{lccl}
\hline \multirow{2}{*}{ Months } & \multicolumn{3}{c}{ Turnover ratio (\%) } \\
\cline { 2 - 4 } & 2015 & 2016 & 2017 \\
\hline Jan & 1.9 & 0.0 & 12.8 \\
Feb & 0.0 & 0.0 & 8.7 \\
Mar & 1.9 & 0.0 & 10.0 \\
Apr & 0.0 & 0.0 & 11.1 \\
May & 0.0 & 0.0 & 5.3 \\
June & 0.0 & 0.0 & 5.3 \\
July & 0.0 & 0.0 & 1.0 \\
Aug & 1.9 & 0.0 & 13.2 \\
Sep & 1.9 & 1.9 & 13.2 \\
Oct & 0.0 & 8.0 & 13.2 \\
Nov & 0.0 & 17.4 & 13.2 \\
Dec & 0.0 & 38.5 & 16.2 \\
& & & 10.2 \\
\hline Total & 0.6 & 5.5 & \\
\hline
\end{tabular}

Table (4): Correlation between work environment and turnover among nursing staff $(\mathrm{N}=40)$.

\begin{tabular}{lcc}
\hline Work environment & \multicolumn{2}{c}{ Turnover } \\
\cline { 2 - 3 } & $r$ & $p$ \\
\hline $\begin{array}{l}\text { Nurse participation in } \\
\text { dialysis provider affairs }\end{array}$ & -0.48 & $0.002^{*}$ \\
Nursing foundations for quality of care & -0.34 & $0.03 *$ \\
Staffing and resource adequacy & -0.05 & 0.73 \\
$\begin{array}{l}\text { Manager ability, leadership } \\
\text { and support of nurses }\end{array}$ & -0.13 & 0.4 \\
$\begin{array}{l}\text { Collegial nurse-physician relations } \\
\text { Total }\end{array}$ & -0.19 & 0.23 \\
\hline
\end{tabular}

\section{Discussion}

The aim of this study is to explore the impact of nursing staff perception of work environment on turnover rate in hemodialysis unit.
In the current study about two thirds of the study subjects were females, this finding could be interpreted in the light of the fact that majority of nurses in Egypt are females and their number are still greater than male in nursing fields till the next ten years. This finding might be congruent with Egyptian Nursing Syndicate, (2012) which mentioned that nursing is a female occupation in Egypt, this gives a reason why the entire study sample was female.

Regarding the educational level of the study subjects, it was found that about more than half of them was diploma nurses, more than quarter were technical nursing institute and the rest were bachelor of nursing and there was the lowest percentage of the nursing power. This finding is consistent with many Egyptian studies such as Mohamed, (2015): And Mohsen \& Fareed, (2013) who reported that more than two third of their study sample were diploma nurses.

Regarding study subjects' age and years of nursing experience, it was observed that about half of the study subjects' ages range between 21-30 years and have 1-5 years of nursing experience at hemodialysis unit and approximately one third of them have 5-9 years of working experience in nursing field. It is agreed with [9], that the majority of nurses' average age was of 29 years and working experience mean $7.0 \pm 6.0$ years.

The result of the current study revealed that work environments in this unit were characterized by poor foundations for quality of care, participation in hospital affairs, nurse-physician team work and also lack of staffing and resources. Our findings are consistent with the findings of other studies, which show that university hospitals experience significant understaffing issues because of high turnover rates among nurses, which has been estimated to range between 5 and $10 \%$ [10] .

The findings that founded in hemodialysis unit at Cairo university hospital as: Lack adequate staffing and resources in addition to nurses not participating in hospital affairs. The low scores for staffing resources and adequacy and nurse participation in hospital affairs found in this study is consistent with findings from another study conducted in Thai hospitals [11].

Researches founded that poor staffing resources explain nurses' job dissatisfaction, intention to leave and turnover. Thus, in order to improve nurses' job satisfaction and reduce burnout and turnover in university hospitals, attention should be paid to improving staffing and resource devel- 
opment. The low participation in hospital affairs should be explored further as this may be due to few opportunities for nurses to participate in setting hospital policy. Nurses might not be actively involved in decision-making processes at unit level. Other studies have also documented low nurse involvement in hospital policy development.

The findings of present study confirmed that poor work environments were correlated with high rates of job dissatisfaction and turnover and conversely supported previous international studies linking negative work environments with job dissatisfaction, intent to leave [12] and turnover. Poor hospital care environments affect patient mortality and nurse outcomes. In hospitals which were inadequately staffed and had the poorest patient care environments, the mortality rate for surgical patients was $60 \%$ higher when compared with hospitals with better care environments, higher staffing levels and the most highly educated nurses. The researchers summate that 40000 deaths per year in the United States could be prevented with improved patient care environments, staffing and education. [13]. The findings of present study imply that better work environments will help nurses to provide better care to patients, increase their job satisfaction and lower intention to leave and turnover.

The findings of present study show there is a high percent of good relationship between staff nurses and medical staff but there is low percent of collaboration and team work between them, these findings of present study are consistent with the findings of other studies, which show that The specialized nature of haemodialysis allows nurses who have gained expertise the ability to be autonomous in deciding care plans for patients [14], and also reflects the limited input medical staff have in the provision of delivering the haemodialysis treatment.

The result of the current study was opposing the result of Cheng [15] about collegial nursephysician relationship and turnover rate that identified a team atmosphere in the work place has been demonstrated to reduce emotional labor and stress leading to less turnover and greater retention of registered nurses. The development and sustaining of effective teams in dialysis units could reduce the stress of coping with the type of work experienced by these nurses.

The findings of present study founded that the turnover ratio has increased dramatically over the years, these findings are consistent with the findings of other studies, where nurses experience emotional distress, compassion fatigue and staff turnover as a result of having intense grief when a patient died whom they had forged a close relationship with Hayes [16]

The study findings highlighted high turnover rate in hemodialysis unit, this finding consistent with other researches findings, high turnover rate were found among hemodialysis nurses and this may be related to unhealthy work environment, lack of resources and staffing, and higher workloads. High levels of turnover in nurses who work in hemodialysis has been shown significantly to affect patient outcomes and satisfaction, retention of the existing nurses and organizational commitment [17].

\section{Conclusion:}

Poor nurse work environment is the underlying factor of nurse attrition and turnover.

\section{Recommendation:}

Based on the finding of the present study the following recommendations were deduced:

- Nurse Managers should be trained to have leadership skills.

- There is a need to foster positive working relationships between nurses and physicians. A high standard of patient care can be achieved through implementation of nursing philosophy, nursing model of care and better standards for nurses' clinical competence.

- Supervisor support should be improved.

- Strong communication between management and workers should be developed.

- Recognition and award system should be encouraged.

- Improved work aids and more exposure to soft skills training should be initiated.

- Flexible work time schedule for workers.

- Keep communication lines open with employees to find out what kind of things or programs would get them motivated. This will also help them feel like they are an important, contributing factor of the hospital.

\section{References}

1- WISKOW C., ALBREHT T. and PIETRO C. De: How to create an attractive and supportive working environment for health professionals. Copenhagen. Report No.: Policy Brief 15, 2010.

2- JANAKIRAMAN R., PARISH J.T. and BERRY L.L.: The effect of the work and physical environment on hospital nurses' perceptions and attitudes: Service quality and commitment. The Quality Management Journal, 18 (4): 36, 2011. 
3- JAIBOON P., CHIANGNANGARM P. and KUHIRUNYARATN P.: The proportion and causes of resignation of nurses from Sribagarid hospital, Khon Kaen University. Srinagarind Medical Journal, 26 (3): 233-238, 2011.

4- NANTSUPAWAT A., et al.: Impact of nurse work environment and staffing on hospital nurse and quality of care in Thailand. Journal of Nursing Scholarship, 43 (4): 426433, 2011.

5- AIKEN L., et al.: Effects of hospital care environment on patient mortality and nurse outcome. Journal of Nursing Administration, 38 (5): 223-229, 2008.

6- AIKEN L., et al.: Importance of work environments on hospital outcomes in nine countries. International Journal for Quality in Health Care, 23 (4): 357-364, 2011.

7- LAKE E.: Development of the practice environment scale of the nursing work index. Research in Nursing \& Health, 25: 176-188, 2002.

8- SEADA: (Rate and causes of turnover among nurses in selected hospitals in Cairo), turnover tool., 1998.

9- AIKEN L., et al.: Patient safety, satisfaction, and quality of hospital care: Cross sectional surveys of nurses and patients in 12 countries in Europe and the United States. British Medical Journal, 344 (7851): 1-14, 2012.

10- KUTNEY-LEE A., WU E. S., SLOANE D.M. and AIKEN L.H.: Changes in hospital nurse work environments and nurse job outcomes: An analysis of panel data. International Journal of Nursing Studies, 50 (2): 195-201, 2013.
11-PATRICIAN P.A., SHANG J. and LAKE E.T.: Organizational determinants of work outcomes and quality care rating among Army Medical department registered nurses. Research in Nursing \& Health, 33 (2): 99-110, 2010.

12- HINNO S., PARTANEN P. and VEHVILAINENJULKUNEN K.: Nursing activities, nurse staffing and adverse patient outcomes as perceived by hospital nurses. Journal of Clinical Nursing, 21 (11-12): 1584-e1593, 2011.

13- KEYSER B.L.: Nephrology Nurses' Job Satisfaction in Chronic Hemodialysis Outpatient Facilities and the Relationship Between Nephrology Nurses' Job Satisfaction and Intent to Stay. Unpublished Thesis. Wilmington University, Wilmington, 2011.

14- KLAUS S.F., EKERDT D.J. and GAJEWSKI B.: Job satisfaction in birth cohorts of nurses. Journal of Nursing Management, 20: 461-471, 2012.

15- CHENG C., BARTRAM T., KARIMI L. and LEGGAT S.G.: The role of team climate in the management of emotional labour: Implications for nurse retention. J. Adv. Nurs., 69 (12): 2812-25, 2013.

16- H AYES B., DOUGLAS C. and BONNER A.: Journal of Nursing Management, 23: 588-598, 2015.

17- International Council of Nurses (ICN): Nurse retention and recruitment: Developing a motivated workforce. Available at: http://www. icn. Ch/global/issue 4 retention FR. pdf Espa., 2014.

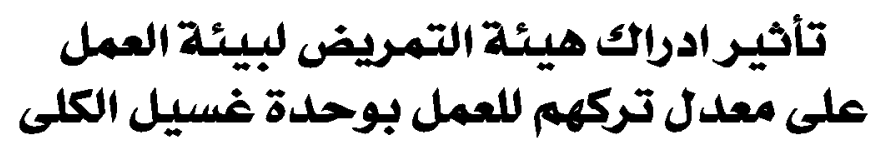

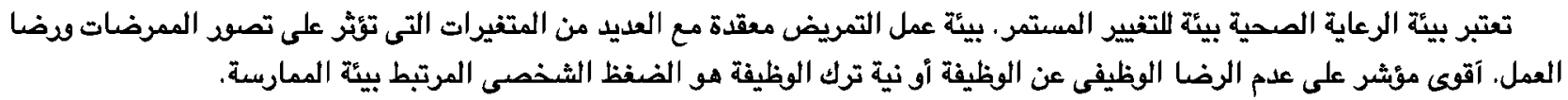

تعمل بيئات العمل السلبية على إبطال معنويات الممرضات والمساهمة في تطوير ظروف عمل غير آمنة، والتى تعتبر غير صعية وترتبط

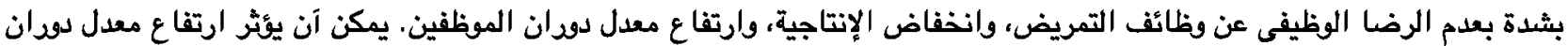

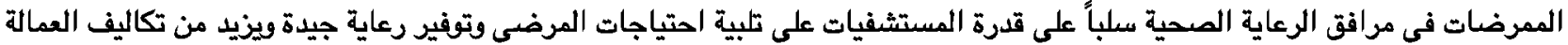
المباشرة وغير المباشرة.

الهدف من البحث: لاستكثاف تاتثير إدراك الممرضات لبيئة العمل على معدل تركهم للعمل فى وحدة غسيل الكلى.

عينة البحت: جميع الممرضات والممرضين العاملين فى الوحدة المختارة (وحدة غسيل الكلى) خلال وقت جمع البيانات في المستشفى الجامعى وعددهـ40.

نتائج البحت: كان أعلى تصعد للممرضات حل أسس التمريض لجودة الرعاية، فى حين كان أدنى تصسو حل التوظيف وكفاية الموارد وكان هناك علاقة عكسية بين تصعد الممرضات لبيئة العمل بشكل عام ومعدل تركهم للعمل، وأيضا كانت هنالك زيادة تدريجية كبيرة في معدل

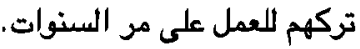

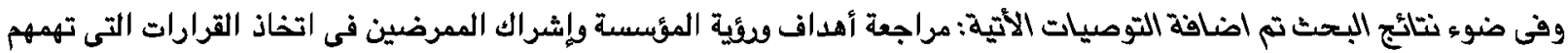

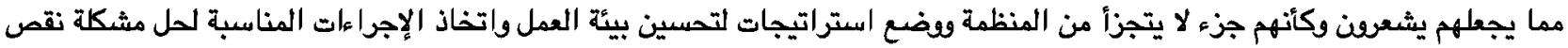
عدد التمريض بالمستشفيات. 